\title{
Training Higher Order Thinking Skills (HOTS) and the Ability to Design Experiments through the Inquiry Lab
}

\author{
I Nurlaelah ${ }^{1}$, Handayani $^{2}$, L Lismaya $^{3}$ \\ ${ }^{123}$ Biology Education, Faculty of Teacher Training and Education, Universitas Kuningan, Indonesia
}

\{1ilah.nurlaelah@uniku.ac.id, ${ }^{2}$ handayani@uniku.ac.id, ${ }^{3}$ lilis.lismaya@uniku.ac.id\}

\begin{abstract}
The research entitled Training Higher Order Thinking Skills (HOTS) and the Ability to Design Experiments through the Inquiry Lab aims to determine critical thinking skills and analytical skills, as well as the ability to design experiments through the application of Inquiry Laboratory models, has been carried out on several selected samples in Kuningan Regency. The target of this research includes information about critical thinking skills, analytical skills, and the ability to design experiments as well as their relationship with the application of the Inquiry Lab. The research method used is experimental research with the One Shoot Case Study design. The sampling technique used purposive sampling. Data were obtained using tests for critical thinking skills, analytical skills, and the ability to design experiments accompanied by rubrics. Several students of Biology Education Study Program level II, level IV, and students in high schools were involved in the research as a sample. The research data were analyzed using a partial t-test, correlation test, and N-Gain. The results of research related to critical thinking skills, analytical thinking, and the ability to design experiments show that there are differences before and after the implementation of the inquiry laboratory model with a sig. (2-tailed) value of $0.000<0.05(\alpha=0.05)$ and the value $\mathrm{N}$-Gain overall in the medium category. The aspects of critical thinking skills and analysis that are measured are positively correlated with the application of the Inquiry Lab. The ability of critical thinking skills has a medium correlation with a correlation value of 0.375 and the ability of analytical thinking skills has a strong correlation with a correlation value of 0.748 . The various abilities to design experiments in each of the measured aspects indicated a varying increase, as well as a positive correlation with a very strong category between the application of the Inquiry Lab model and the ability to design experiments indicated by a correlation value of 0.904 .
\end{abstract}

Keywords: Implementation; Education; Character

\section{Introduction}

Learning is a complex process because learning activities always integrate various components and activities, namely students with a learning environment to obtain behavior change (learning outcomes) by the expected goals (competencies). Each individual or student faced by educators is very complex because it involves physical and psychological aspects. The behavior to be generated from learning is also complex, because it involves various 
abilities (competencies) such as cognitive, affective, and psychomotor elements. Likewise, the interaction of learning and the learning environment itself is complex, because it involves the material, approaches, models, strategies, methods, and media used in communicating with students to obtain the expected learning objectives (competencies) [1]. The development of student potentials in the learning process must be carried out thoroughly. In the learning process in the classroom, lecturers are not only armed with knowledge regarding the field of study being taught but need to pay attention to the aspects of learning holistically that support the realization of the development of the potentials of students [2].

Learning activities both in the classroom or in the laboratory to develop student potential must contain 21 st-century skill components such as Strengthening Character Education (PPK), 4C (Literacy, Critical Thinking, Creative Thinking, Collaboration, and Communication), and Higher-Level Thinking Skills (HOTS). These thinking skills are needed by students in understanding Biology where students' understanding in studying biology is not only limited to understanding concepts. Biology understood and studied by students cannot be separated from the application of the nature of science which consists of processes, products, and attitudes. Biology learning is carried out so that students can understand and master the concepts, principles, and theories as a basis for mastering more complex scientific products. Science products are obtained through scientific processes which are included in scientific inquiry, including thorough investigation activities to seek truth or knowledge through scientific processes such as formulating problems, formulating hypotheses, designing experiments, collecting data, analyzing, and finally concluding. The scientific attitude in learning science aims at cultivating and developing attitudes such as curiosity, thoroughness, hard work, and other attitudes that encourage a scientist to carry out scientific investigations. Therefore, biology must be taught to students as a whole in terms of scientific attitudes, scientific processes, and scientific products, so that in the end the knowledge they gain can be applied in everyday life [3].

Understanding biology, which is sometimes abstract, cannot be understood only in theory, to make it easier to understand abstract concepts laboratory activities are needed to support a deeper understanding of biological concepts. Laboratory activities are an important component of biology learning. Laboratory activities are essentially aimed at helping students develop understanding, cognitive abilities, critical thinking, creative thinking, and scientific attitudes through their involvement in hands-on activities [4], where it is through this process that the actual goal of practicum can be achieved. The form of practicum that can facilitate and develop higher-order thinking skills, especially critical thinking skills and analytical thinking skills, is designing experiments. Through designing experiments students develop thinking skills through the stages of the scientific method.

Laboratory activities are essentially aimed at helping students develop understanding, cognitive abilities, critical thinking, creative thinking, and scientific attitudes through their involvement in hands-on activities [4]. A laboratory activity model that facilitates the application of the scientific method is the Inquiry Lab. Conventional laboratory activity models have low cognitive guidance, on the other hand, Inquiry Lab activities provide opportunities for students to develop thinking and reasoning skills either quantitatively or qualitatively. Conventional has low cognitive guidance, on the other hand, Inquiry Lab activities provide opportunities for students to develop thinking and reasoning skills either quantitatively or qualitatively.

Experiments in the form of an Inquiry lab are designed to start from students' prior knowledge in finding a problem. Based on the identification of this problem, students design experiments to find solutions to these problems through practicum activities. This kind of 
laboratory activity encourages thinking skills such as critical thinking, analytical thinking, describing knowledge effectively, interpreting concepts or principles, building concepts, and scientific representation. These important concepts and principles are built through prediction, testing predictions, inference, and cognitive conflict. Besides emphasizing thinking skills, experimental activities in the Inquiry Lab are also expected to encourage students' ability to design experiments through the Inquiry Lab model syntax based on scientific methods, so that they are trained to design an experiment.

This is what underlies the researcher to reveal the extent to which the application of Inquiry Lab can improve and correlate with higher-order thinking skills, especially critical thinking skills and analytical thinking skills as well as students' abilities in designing experiments.

\section{Method}

The research was conducted at the P. Biology Study Program, FKIP, Kuningan University. The research was conducted during the even semester of the 2019/2020 academic year, on students of the Biology Education program of Faculty of Social and Political Sciences, Kuningan University. The sampling technique used purposive sampling. The samples taken in this study were 28 students Department of the Biology Study Program who took plant anatomy and microbiology courses, and 26 students in level IV who took agribusiness courses. The research method used in this research is experimental research with a one-shot case study design. This study aims to determine the application of laboratory inquiry to higher-order thinking skills, namely critical thinking skills and analytical skills as well as the ability to design experiments. The data analysis technique used is the partial $t$-test and to determine the correlation of each of the higher-order thinking skills and the ability to design experiments used the correlation test.

The instruments used in this study were the critical thinking ability test according to Ennis, the analysis ability test according to Marzano, the ability to design experiment rubric, and the observation sheet accompanied by the Inquiry Lab rubric. Inquiry Lab learning stages according to [5] includes the following steps:

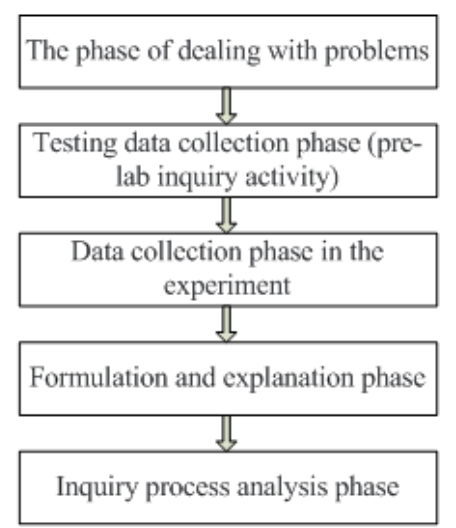

Fig 1. Inquiry Lab Learning Stages 


\section{Result and Discussion}

This research aims to determine the improvement of critical thinking skills, analytical thinking, and the ability to design experiments before and after the application of the Inquiry $\mathrm{Lab}$ and the relationship between the application of Inquiry Lab and critical thinking skills, analytical thinking skills, and the ability to design experiments. Critical thinking and analytical thinking skills were assessed using tests, while the ability to design experiments was assessed using the experimental designing rubric. The application of the Inquiry Lab is assessed using an observation sheet accompanied by a rubric.

\subsection{Eenhancement of Higher-Order Thinking Skills and Ability to Design Experiments.}

Critical thinking and analytical thinking skills as well as the ability to design experiments were assessed before and after the application of the Inquiry Lab to determine the increase. The N-gain value of critical thinking skills, analytical thinking, and the ability to design experiments is presented in table 1 below:

Table 1. Average Value and N-Gain of Higher-Order Thinking Skills and Ability to Design

\begin{tabular}{llllll}
\multicolumn{9}{c}{ Experiments } \\
\hline \multirow{2}{*}{ No } & Variable & \multicolumn{2}{c}{ Average Value } & \multirow{2}{*}{ N-Gain } & Category \\
\cline { 3 - 5 } & & Before & After & & \\
\hline 1 & Critical Thinking Skills & 78,5 & 82 & 0,35 & Medium \\
2 & Analytical Thinking Ability & 60,6 & 75,3 & 0,37 & Medium \\
3 & Ability to Design Experiments & 21 & 64 & 0,5 & Medium \\
\hline
\end{tabular}

Assessment before and after the application of Inquiry Lab showed an increase in the mean value of critical thinking skills, analytical thinking, and experimental design abilities. The NGain results showed that critical thinking skills, analytical thinking, and the ability to design experiments were all in the medium category improvement.

\subsection{Correlation Test of Application Lab Inquiry Against High-Level Thinking Skills (HOTS) and the Ability to Design Experiments}

Partial t-test and linear correlation test were conducted to determine the significant relationship between the application of Inquiry Lab and higher-order thinking skills consisting of critical thinking skills and analytical thinking skills and the ability to design experiments. The results of the analysis are presented in table 2 below:

Table 2. Hypothesis Test Results of the Application of Inquiry Lab on Critical Thinking Skills, Analytical Thinking Skills, and Designing Experiment Ability

\begin{tabular}{lllll}
\hline No & Variable & Sig. & $\begin{array}{l}\text { Correlation } \\
\text { Value }\end{array}$ & Category \\
\hline 1 & Critical Thinking Skills & 0,000 & 0,375 & Medium \\
\hline 2 & Analytical Thinking Skills & 0,000 & 0,748 & Strong \\
\hline 3 & Designing Experiment Ability & 0,000 & 0,904 & Very Strong \\
\hline
\end{tabular}

Based on the analysis results obtained a significant correlation between the application of the Inquiry Lab on critical thinking skills, analytical thinking, and the ability to design experiments with a significance value of $0.000<0.005$ where each relationship has a different correlation value. Application of Inquiry Lab has a moderate correlation with critical thinking 
skills, while analytical thinking skills have a strong correlation. The application of the Inquiry Lab has a very strong correlation with the ability to design experiments.

\subsection{The Relationship between Application of Inquiry Lab and Critical Thinking Skills}

Based on the average value obtained, it shows that the posttest mean score of critical thinking skills of students who follow the Inquiry Lab learning model is greater than the pretest average value of critical thinking skills. This indicates that the achievement of critical thinking skills of students who take learning using the Inquiry Lab learning model gives good results proven by an increase in the posttest results of critical thinking skills. This is in line with the theories previously described. According to [6], the Inquiry Lab model is a series of learning activities that maximally involves all student skills to seek and investigate systematically, critically, logically, analytically, so that students can formulate their findings confidently. The Inquiry Lab learning model is one of the innovative learning models that are appropriate for use in science learning, especially biology because it can develop students' skills to understand and acquire knowledge through systematic and scientific thinking. Inquiry Lab prioritizes student activities in the process of learning activities where students build knowledge and understanding of how a scientist works. Each of these levels of inquiry includes intellectual skills and scientific performance [7].

Based on the result, students' critical thinking skills per indicator are spread over 3 categories, namely very high, high, and medium. Students' critical thinking skills in elementary clarification are in the very high category, basic information, inferences, and determining strategy and tactics are in the high category. The clarification indicator is in the medium category. The relationship between indicators of critical thinking and the inquiry lab will be discussed as follows:

\section{a. Indicator 1: Elementary clarification (provides a simple explanation)}

Based on the result, students' critical thinking skills are very high on the elementary clarification indicator (giving a simple explanation) because the experiment is in the form of an Inquiry lab, one of the phases is the phase of dealing with problems, at this stage student are faced with a problem, including by presenting conflicting situations. The lecturer explains an outline of the research procedures to be carried out. In this case, the lecturer guides students by asking supervisor questions. Students also have to use some of their process skills in providing simple explanations [8], also because in learning activities students are given student worksheets (LKM) which contain problems by presenting conflicting situations so that students can provide simple explanations regarding the problems presented.

\section{b. Indicator 2: Basic information (gather basic information)}

Students' critical thinking skills on basic information indicators (collecting basic information) reach a high category, of course, cannot be separated from the use of the Inquiry Lab learning model, wherein this inquiry lab learning students collect as much information as possible about the problems they face. This data can be obtained based on the condition or nature of the object by examining how the process occurs. Then students formulate hypotheses (create relationships with something that is known). Besides, because the inquiry lab is a laboratory activity based on the active participation of students in the data collection process and provides an analysis of the facts of the results obtained [9]

\section{c. Indicator 3: Inferences / concluding}

In the conclusion indicator, students' critical thinking skills are in the high category because with the inquiry lab learning model, especially in the formulation and explanation phases 
students are trained to organize and analyze data, connect with hypotheses, predict, select findings that are following what is known, then interpret it (conclude) [8].

\section{d. Indicator 4: Making further explanation}

In learning with the Inquiry Lab learning model with indicators of making further explanations, the category is moderate, this is because students are facilitated by the Inquiry Lab model to present the information they get and provide further clear descriptions, namely in the formulation and explanation phases. Thus students are trained to make further explanations [8].

\section{e. Indicator 5: Implementing strategies and techniques}

Based on the result, the high level of implementing strategies and techniques with the Inquiry Lab learning model is because students with the guidance of the researcher discuss the strategies produced by each group member to choose the right strategy to complete the tasks in the MFI completed well. In completing the evaluation test, the strategies used by almost all students were able to complete well. So students are familiar with implementing strategies and techniques. Besides, the skills to apply these strategies and techniques are also facilitated by the inquiry lab phase, namely the inquiry process analysis phase, wherein this phase student are asked to analyze the research process to obtain more effective procedures, or determine findings that can be used to predict other phenomena by designing procedures new [8].

From the description above, it can be concluded that carrying out the Inquiry lab learning process can facilitate students' critical thinking skills on each indicator. From table 7 it can be seen that there are no students who have low or very low critical thinking skills. Students' critical thinking skills are in the very high, high, and medium categories. This proves that the Inquiry lab learning model can facilitate students' critical thinking skills. Learning must involve providing various situations in which children are used to experimenting or trying out various things to see what is happening, manipulating objects, symbols, asking questions and finding their answers, reconciling what they have found at one time with what they have found at the same time. others compared their findings with those of other children [10].

Inquiry Learning Lab, apart from being oriented towards learning outcomes, is also oriented towards the learning process. It aims to develop thinking skills. Students' critical thinking skills can be done by always asking and questioning various phenomena that are being studied [11]. Based on the description above, both from a theoretical perspective and the presentation of learning, it is proven that Inquiry Lab learning can facilitate students to improve critical thinking skills. These results are also supported by several previous studies including. [12], [13], [14] and [15].

\subsection{The Relationship between Application Lab Inquiry and Analytical Thinking Skills}

Inquiry Lab is a laboratory learning model that emphasizes scientific activities where students carry out a series of laboratory activities that begin with finding problems. Students act like scientists to find solutions to problems by following a scientific process [16]. Laboratory-based inquiry requires students to seek knowledge, make hypotheses, collect data, interpret evidence, and make conclusions [17]. In line with [18] through scientific inquiry students determine problems, develop solutions and alternative solutions to these problems, seek information, evaluate information, and communicate with their friends. In this laboratory learning model, students design experiments instead of following the verification process, they try to achieve scientific concepts on their own and develop high-level cognitive skills [19]. One of the higher-order cognitive skills is analytical thinking skills which, according to Marzano, are part of higher-order thinking skills [20]. 
Analytical thinking skills can be developed through laboratory activities [21] for example through Inquiry learning where a series of learning activities emphasize critical thinking processes and analysis to solve problems based on the facts found and designed to achieve conceptual understanding [22]. The inquiry learning model helps students to develop their analytical thinking and enables them to build knowledge like scientists do [23]. Important analytical thinking skills are developed so that students can process the information or data they get which can then be linked and applied in everyday life. Through analytical thinking skills, students can also identify an event, connect and combine data from various sources, and draw logical conclusions and sharpen students in thinking [24].

Analytical thinking guides someone in processing information, when someone has the required basic information about a topic, someone can collect the data. This is where thinking analysis comes into play where one can discover how the information obtained varies and relates to one another. They learn about the dynamic nature of the information. They analyze which parts depend on other parts, and which parts are free. They learn how to relate new learning to prior knowledge and learn what might occur in very different content areas. They initiate the process of searching for when and how new information might be useful [25]. Syntax in Inquiry Lab learning helps students develop analytical thinking skills.

Indicators of analytical thinking skills to classify and analyze errors are developed when students find a problem that must be solved. At the data collection stage, both pre-lab activities and experimental data collection, adjustment, and classification indicators are needed by students to be able to formulate a hypothesis and sort out the appropriate data to solve a problem. While generalization and specification indicators are developed as long as students are in the formulation and explanation stages and in the stage of analyzing the inquiry process. It is at this stage that aspects of concept use are trained and verified by communicating it to other friends [26] and students' analytical thinking skills are trained when concluding [27]. Each stage of inquiry can guide students to find concepts, analyze, apply, synthesize, and evaluate information as well as decide what to believe and do [28]. This is why the application of Inquiry Lab has a significant and strong correlation with analytical thinking skills.

Analytical thinking skills have increased even though they are in the medium category after the Inquiry Lab learning model is applied. Through this learning model, it can activate students in constructing concepts. Inquiry Lab is applied to foster thinking skills, develop cognitive processes, work scientifically, help students become lifelong learners, and communicate these abilities as an important aspect of life skills [29].

\subsection{Relation of Application of Lab Inquiry with Ability to Design Experiments}

Data on the ability to design student experiments sampled in this study were obtained through the ability to design experiments conducted before (pre-test) and after (post-test) the implementation of laboratory inquiry model learning. The ability to design student experiments as a whole has increased. Table 1 shows the descriptions of the pretest and posttest data, the data illustrates that the ability to design students' experiments increases after the implementation of learning. The ability to design measured experiments includes seven adapted and modified aspects of the research skills development assessment (RSD) matrix from [30], namely: 1) identifying problems, 2) formulating problems, 2) developing hypotheses, 4) making designs, 5) collecting data, 6) analyzing data, and 7) making conclusions. The measurement results show an increase in the mean value of pre-test to posttest scores. 
The results of the Pearson correlation test analysis show that there is a positive correlation between learning laboratory inquiry models and the ability to design experiments indicated by a significance value $(2$-tailed $)<(\alpha=0.01)$ and $r$ count $(0.904)>r$ tab, $(\alpha=0.01)(0.641)$. The profile of the various abilities to design experiments in each of the measured aspects shows a varying increase for each aspect of the indicator. However, overall, it shows an increase with an increase in the value from the low to medium category. Based on the findings on the implementation of inquiry lab learning as in Table 1 and Table 2, the ability to design students' experiments increased after the implementation of laboratory inquiry learning. Learning experiences in the laboratory such as experimental activities are important experiences to provide an inquiry learning experience in the laboratory.

Experimental and practical activities allow students to interact with the scientific phenomenon that is being studied. The interaction of students with the object of study or scientific phenomena will be able to develop certain skills needed in the investigation process as well as to develop several other skills and knowledge of students. According to [31] learning activities in the laboratory can support the development of mastery of High Order Learning Skills such as making observations, designing and conducting experiments, asking questions, formulating hypotheses, and analyzing experimental results. The implementation of the laboratory inquiry learning model provides learning experiences for students to be able to practice several skills including making problem formulations and hypotheses, students can identify problems, re-design trials, process different data, generate data, interpret data, make conclusions, etc. indirectly train the ability of high order learning skills.

The inquiry itself can be defined as a way to gain an understanding of science content [8]. The inquiry is a process for students to solve problems, plan and conduct experiments, collect and analyze data, and draw conclusions [32]. Students need learning experience in the laboratory to gain experience in constructing their scientific experience. The increase in the ability to design experiments shown in Table 1 and Table 2 proves that the implementation of the laboratory inquiry model has succeeded in providing a very meaningful learning experience in constructing scientific experiences for students, even though the increase is in the moderate category (Gain 0.5 ).

According to [33], laboratory activities are all experimental activities used in science learning in schools, both in demonstrations and experiments conducted in the classroom or laboratory. The implementation of the laboratory inquiry model in this study is divided into two activities, namely pre-lab activities and laboratory inquiry activities. The pre-lab activity was preceded by a problem, both proposed by students and given by the teacher/lecturer. From these problems, students make hypotheses or provisional assumptions in the form of answers based on initial knowledge. Then in the inquiry activity, students are given the broadest freedom possible to identify and conduct research to find new concepts. [34] stated that experimental activities carried out in the laboratory function in the process of cognition, one of which emphasizes problem-solving learning.

Other general objectives of laboratory activities described by Bayraktar et al [35] include: supporting or strengthening theoretical knowledge, making fun discoveries, developing students' psychomotor skills, teaching scientific knowledge, can be applied in everyday life applications, increasing thinking skills creative, provides benefits in the scientific method, higher-order thinking skills, develops communication skills, develops manual dexterity using tools and equipment, allows students to apply skills instead of memorizing. Thus the implementation of the laboratory inquiry model through experimental activities has been able to provide learning experiences about how students construct their scientific experiences. 
The finding of a strong and positive relationship between students' ability to design experiments with the implementation of laboratory inquiry models was proven through correlation test data which showed a high correlation value $(r=0.904)$. This provides an understanding of the strong relationship between activity in the laboratory through the implementation of the laboratory inquiry model with the ability to design students' experiments. According to Hebrank (2000) in [32] proposing inquiry is the art of asking natural science questions about natural phenomena and finding answers to these questions. Inquiry involves observing, taking measurements, hypothesizing, interpreting, building theory, planning investigations, experimenting, and reflecting.

Furthermore [32] said that Inquiry requires identification of assumptions, thinking logically, and thinking critically, and considering alternative explanations. In line with the above opinion, the results of the study [36] say that inquiry is the spirit that underlies a person studying science and inquiry carried out in learning practices in the laboratory through practicum activities and/or experiments have been able to provide experience to students in developing higher-order thinking skills (HOTs) and train the ability to research students.

\section{Conclusion}

Inquiry Lab is effective in improving higher-order thinking skills both critical thinking skills and analytical thinking skills as well as the ability to design experiments in the medium category. Besides, the application of Inquiry Lab has a moderate correlation with critical thinking skills, has a strong correlation with analytical thinking skills, and has a very strong correlation with the ability to design experiments.

\section{References}

[1] Rusman. (2011). Model-Model Pembelajaran Mengembangkan Profesionalisme Guru. Jakarta: PT. Rajagrafindo Persada.

[2] Aunurrahman. 2011. Belajar dan Pembelajaran. Bandung: Alfabeta

[3] Handayani and Setiawati, I. (2015). Efektivitas Pembelajaran Biokimia Dengan Model Pembelajaran Inkuiri Dipadu Vee Diagram Terhadap Keterampilan Proses Sains Dan Pemahaman Konsep Pada Mahasiswa Dengan Kemampuan Akademik Atas Dan Bawah. Quagga: Jurnal Pendidikan Biologi. 7(1),

[4] Suma, K. (2005). Efektivitas kegiatan laboratorium konstruktivis dalam meningkatkan penguasaan konsep-konsep arus searah mahasiswa calon guru. Jurnal Pendidikan dan Pengajaran IKIP Negeri Singaraja. 38(2), $159-171$

[5] Wenning, C.J. (2010). Levels of inquiry: Using inquiry spectrum learning sequences to teach science. Journal of Physics Teacher Education. Online. 5(4), 11-19

[6] Ennis, R.H. (1996). Critical Thinking. New York : New York Times Company.

[7] Ermayanti, Sulisworo, D. (2016). Tingkat Kemampuan Berpikir Kritis Peserta Didik setelah Penerapan Model Pembelajaran Student Team Achievement Divisions (STAD) pada Siswa Sekolah Menengah Atas (SMA). Prosiding Seminar Nasional Quantum. Universitas Ahmad Dahlan.

[8] Gulö, W. 2005. Metodologi Penelitian. Jakarta: PT Grasindo.

[9] Wenning, C. 2005. Implementing inquiry based instruction in the science classroom: A new model for solving the improvement of practice problem. Journal Physics Teacher Education Online. 2(4). 9-15. 
[10] [10] Wenning, C.J. (2007). Assessing Inquiry Skills as a Component of scientific literacy. J.Phys. Tchr. Educ. Online. 4,(2)

[11] Koray, O \& Koksal, M.S. (2009). The effect of creative and critical thinking based laboratory applications on creative and logical thinking abilities of prospective teachers. Asia-Pacific Forum on Science Learning and Teaching, Volume 10, Issue 1, Article 2, p.1

[12] Lismaya, L. "Penerapan Pembelajaran Biokimia Berbasis Student Center Learning (SCL) Terhadap Kemampuan Pemecahan Masalah Mahasiswa," BioEdUIN Journal Program Studi Pendidikan Biologi, vol. 7, no.1, pp. 1-11, 2017.

[13] Lismaya, L. "Pengaruh Model Pembelajaran Berbasis Masalah terhadap Kemampuan Berpikir Kritis Mahasiswa Pada Konsep Spesiasi," Quagga Jurnal Pendidikan dan Biologi, vol. 9, no 01, pp. 73-80, 2017.

[14] Setiawan, I. G. N. (2005). Pengaruh Pembelajaran Konstektual dalam Strategi Inquiri dan Pembelajaran Masalah untuk Meningkatkan Kemampuan Berpikir dan Penguasaan Konsep Biologi Siswa SMP di Kecamatan Buleleng Bali. Disertasi (Tidak Diterbitkan). Malang: Universitas Negeri Malang.

[15] Mertayasa, I Made Ari. (2012). Pengaruh Model Pembelajaran Cooperative Guided Inquiry Labs dan Individual Guided Inquiry Labs terhadap Pemahaman Konsep dan Keterampilan Berpikir Kritis Fisika siswa ditinjau dari Gaya Kognitif". e-Journal Program Pascasarjana Universitas Pendidikan Ganesha, Program Studi Pendidikan IPA. Vol. 2(1), 125-133.

[16] Anggraeni, N.w. (2012). Implementasi Strategi Pembelajaran Inkuiri Terhadap Kemampuan Berpikir Kritis dan Pemahaman Konsep IPA Siswa”. E-journal Program Pascasarjana Universitas Pendidikan Ganesha, Program Studi Pendidikan IPA. 3 (1), 78-87.

[17] Rangkuti, M. A. dan Asmin. (2012). "Analisis Kemampuan Berfikir Kritis Menyelesaikan Masalah Fisika dan Gaya Belajar Siswa Pada Pembelajaran dengan Model Pembelajaran Inquiry Lab". Journal online Pendidikan Fisika, Pascasarjana Universitas Negeri Medan. Volume 1 (2).

[18] Sotiriou, S \& Bogner, F.X. (2015). A 2200-Year Old Inquiry-Based Hands-On Experiment in Today,s Science Classroom. World Journal of Education. 5(2). 52-62.

[19] Chang, K. E, Sung, Y. T, \& Lee, C. L. (2003) Web-Based Collaborative Inquiry Learning. Journal of Computer Assisted Learning. 19, 56-69.

[20] Katsampoxaki-Hodgetts, K, Fouskaki, M, Siakavara, K, Moschochoritou, R \& Chaniotakis, N. (2015). Students and Teacher Perception of Inquiry-Based Science Education in Secondary Education in Greece. American Journal of Educational Research. 3(8), 968-976.

[21] Ural, E. (2016). The Effect of Guided Inquiry Laboratory Experiments on Science Education Student's Chemistry Laboratory Attitudes, Anxiety, and Achievement. Journal of Education and Training Studies. 4(4).

[22] Heong, Mei, Yee, et.al., 2011, The Level of Marzano Higher Thinking Skills Among Technical Education Students, International Jurnal of Social Science and Humanity, Vol 1 (2):121-125

[23] Anwar, B \& Mumthas, N.S. (2014). Taking Triachic Teaching to Classrooms: Giving Everybody a Fair Chance. Journal of Advanced Research. 2 (455-458)

[24] Ketpichainarong, W, Panjipan, B, \& Ruenwongsa. (2010). Enhanced Learning of Biotechnology Students by Inquiry-Based Cellulase Laboratory. International Journal of Environmental and Science Education. 5(2), 169-187.

[25] Corlu, M.A, Corlu, M.S. (2012). Theory and Practice. 12,1 (514-521).

[26] Pally, M. (2001). Skills Development in Sustained Content-Based Curricula: Case Study in Analytical/Critical Thinking and Academic Writing Language and Education. 15(4), 279-305.

[27] Hindriana, A. F. (2020). Penurunan beban kognitif untuk meningkatkan kemampuan analisis konseptual. Proceeding Seminar PGSD. Universitas Kuningan

[28] Blanchard, M. R., Southerland, S. A., Osborne, J. W., Sampson, V. D., Annetta, L. A., \& Granger, E. M. (2010). Is inquiry possible in light of accountability?: A Quantitative comparison of the relative effectiveness of guided inquiry and verification laboratory instruction. Science Education, 94(4), 577-616. https://doi.org/10.1002/sce.20390

[29] Abrami, P. C., Bernard, R. M., Borokhovski, E., Wade, A., Surkes, M. A., Tamim, R., \& Zhang, D. (2008). Instructional Interventions Affecting Critical Thinking Skills and Dispositions: A Stage 1 
Meta-Analysis. Review of Educational Research, 78(4), 1102-1134. https://doi.org/10.3102/0034654308326084

[30] Irwanto, Saputro, A. D, Rohaeti, E, Prodjosantoso, A.K. (2019). Using Inquiry-Based Laboratory Instruction to Improve Critical Thiinking and Scientific Process Skills Among Preservice Elementary Teachers. Eurasian Journal of Educational Research. 80, 151-170.

[31] Wahyuni, T.S \& Analita, R.N. (2017). Guided-Inquiry Laboratory Experiments to Improve Students' Analytical Thinking Skills. Aip Conference Proceedings.

[32] Willison, J. W \& O'Regan, K. (2007). Commonly known, commonly not known, totally unknown: a framework for students becoming researchers. Higher Education Research \& Development, 393409.

[33] Katchevich D., Hofstein A. \& Mamlok R. (2013). Argumentation in the chemistry laboratory: inquiry and confirmatory experiment. Res Sci Edu. 43:317-345.

[34] Rustaman, N.Y. (2005). Perkembangan Penelitian Pembelajaran Berbasis Inkuiri dalam Pendidikan Sains. Makalah dipresentasikan dalam Seminar Nasional II Himpunan Ikatan Sarjana dan Pemerhati Pendidikan IPA Indonesia bekerjasama dengan FMIPA Universitas Pendidikan Indonesia Bandung, 22-23 Juli 2005. FPMIPA UPI.

[35] Nivalainen, V., Asikainen, M. A., Sormunen, K., \& Hirvonen, P. E. 2010. "Preservice and Inservice Teachers' Challenges in the Planning of Practical Work in Physics". Science Teacher Education, 293-409.

[36] Bílek, M.t., \& Skalická, P.A. 2009. "Real, Virtual Laboratories Together in General Chemistry Education: Starting Points for Research Project". Problems of Education In The 21st Century, 3039.

[37] Dikmenli, M. 2009. "Biology student teachers' ideas about purpose of laboratory work". AsiaPacific Forum on Science Learning and Teaching

[38] Nurlaelah, I., Widodo, A., Redjeki, S., Rahman, T. (2020). Student's Research Skills in middle school of Kuningan district. Journal of Physic: conference series. 1521:042105 